\title{
Effects of Sunflower Meal Supplementation as a Complementary Protein Source in the Laying Hen's Diet on Productive Performance, Egg Quality, and Nutrient Digestibility
}

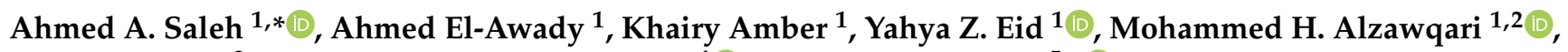 \\ Shaimaa Selim ${ }^{3}$, Mohamed Mohamed Soliman ${ }^{4}$ (D) and Mustafa Shukry ${ }^{5, *(D)}$ \\ 1 Department of Poultry Production, Faculty of Agriculture, Kafrelsheikh University, \\ Kafrelsheikh 333516, Egypt; elawody@gmail.com (A.E.-A.); khairyamber1957@gmail.com (K.A.); \\ yahya.eid@agr.kfs.edu.eg (Y.Z.E.); m.alzawqari@gmail.com (M.H.A.) \\ 2 Department of Animal Production, Faculty of Agriculture and Veterinary Medicine, Ibb University, \\ Ibb 70270, Yemen \\ 3 Department of Nutrition and Clinical Nutrition, Faculty of Veterinary Medicine, Menoufia University, \\ Shibin El-Kom 32514, Egypt; shimaaselim@vet.menofia.edu.eg \\ 4 Clinical Laboratory Sciences Department, Turabah University College, Taif University, P.O. Box 11099, \\ Taif 21944, Saudi Arabia; mmsoliman@tu.edu.sa \\ check for \\ updates \\ Citation: Saleh, A.A.; El-Awady, A.; \\ 5 Department of Physiology, Faculty of Veterinary Medicine, Kafrelsheikh University, \\ Kafrelsheikh 33511, Egypt \\ * Correspondence: ahmed.saleh1@agr.kfs.edu.eg (A.A.S.); mostafa.ataa@vet.kfs.edu.eg (M.S.)
} Amber, K.; Eid, Y.Z.; Alzawqari, M.H.; Selim, S.; Soliman, M.M.; Shukry, M. Effects of Sunflower Meal Supplementation as a Complementary Protein Source in the Laying Hen's Diet on Productive Performance, Egg Quality, and Nutrient Digestibility. Sustainability 2021, 13, 3557. https://doi.org/ $10.3390 /$ su13063557

Academic Editors: Marc A. Rosen and Nikola Puvača

Received: 14 February 2021

Accepted: 20 March 2021

Published: 23 March 2021

Publisher's Note: MDPI stays neutral with regard to jurisdictional claims in published maps and institutional affiliations.

Copyright: (c) 2021 by the authors. Licensee MDPI, Basel, Switzerland. This article is an open access article distributed under the terms and conditions of the Creative Commons Attribution (CC BY) license (https:// creativecommons.org/licenses/by/ $4.0 /)$.

Abstract: The practical usage of untraditional feedstuffs such as sunflower meal (SFM) in laying hens nutrition in developing countries has received considerable attention. SFM is a by-product of the sunflower oil industry and has been progressively added to bird's diets. Sunflower meal (SFM) is gaining great interest as a feed ingredient due to its eminent crude protein content, low anti-nutritional compounds, and low price. The current experiment was aimed to assess the production efficiency, egg quality, yolk fatty acids composition, and nutrient digestibility of laying hens fed SFM. A total of 162 Bovans Brown laying hens aged 60 weeks old were randomly allocated using a completely randomized design into three experimental groups of nine replicates each ( $n=\operatorname{six} /$ replicate) for eight weeks. The dietary treatments involved a control (basal diet) and two levels of SFM, 50 and $100 \mathrm{~g} / \mathrm{kg}$ feed. The dietary treatments did not influence live weight gain, feed intake, and egg mass. On one hand, the laying rate was increased; on the other hand, the feed conversion ratio and broken eggs rate of laying hens were decreased $(p<0.05)$ by the dietary inclusion of SFM. Dietary treatments had no effect on the egg's quality characteristics except the yolk color and yolk height were larger $(p=0.01)$ for laying hens fed SFM compared with those fed the control. Dietary inclusion of SFM decreased $(p<0.05)$ the content of cholesterol in the egg yolk. Still, it increased the yolk contents of vitamin E, calcium, linoleic acid, linolenic acid, and oleic acid $(p<0.05)$. Furthermore, the dietary inclusion of SFM increased crude protein and calcium digestibility, but decreased the ether extract digestibility. In conclusion, our results suggested that the dietary inclusion of SFM, up to $100 \mathrm{~g} / \mathrm{kg}$ at a late phase of laying, could improve the production performance, some of the egg quality traits, and nutrient digestibility while decreasing egg yolk cholesterol.

Keywords: sunflower meal; laying hens; performance; yolk cholesterol; yolk fatty acids; egg quality

\section{Introduction}

In the practical poultry industry, higher feed ingredient prices have led to a closer consideration to seek less expensive agricultural by-products [1]. Sources of protein are becoming more and more limited around the world. Consequently, there is a need to search for alternative protein sources [2]. In general, feed costs reflect much of the expenses, and 
abrupt increases in feed costs make it a contest for nutritionists to sustain animal production and safety while balancing the cost of the diet [3]. Soybean meal (SBM) is one of the most popular sources of protein used in poultry diets. When the price rises, nutritionists must choose the available ingredients to formulate cheap, balanced, and economically viable diets $[4,5]$. In this context, developing diet formulations with alternative ingredients is the best to overcome this problem and reduce feed costs, especially when these alternative ingredients are locally available.

Sunflower can be harvested in tropical areas two or three times a year, and it is a healthy substitute for the oil manufacturers and the feed mill district [6]. Sunflower meal (SFM) is an invention from the oil extraction of sunflower seed, and it is utilized primarily as protein and fiber sources in the diets of poultry [4,5,7-9]. Although SFM is opulent in crude protein, its poultry applications have some limitations due to its relatively extreme fiber including insoluble fiber and low levels of specific limiting amino acids such as lysine and methionine. Additionally, sunflower seeds have a high content in $\alpha$-tocopherols (608 $\mathrm{mg} / \mathrm{kg}$ seed) with efficient antioxidants. Therefore, sunflower is deemed as a plentiful source of vitamin E [10]. Compared with other oilseed meals, SFM is considered a good Ca, P, and vitamin B-complex [11]. Due to its low anti-nutritional and toxic compounds, sunflower proteins are considered an attractive alternative feed ingredient to replace SBM [12]. Researchers have extensively studied the potential functional properties of defatted oilseed meals [13]. Therefore, it is important to realize that the differences in its nutrient contents restrict the application of SFM in the poultry fed due to the different ways in the seeds' processing. SFM can be utilized in the diet of laying hens with no negative impact on the egg quality parameters [7,14-16]. By-products such as SFM contain high fiber and linoleic acid (a laying hen's fat source); the by-products are marketed for various world areas [17,18]. Fafiolu et al. [19] found that SFM is an excellent source of crude protein, ether extract, and amino acids, and it can be a substitute for SBM as feedstuff. SFM contains significant cell-wall components and high fiber content that may perform a crucial role in minimizing the blood cholesterol level. Baghban-Kanani et al. [8] revealed that the inclusion of SFM up to $20 \%$ of the laying hens' diets with multi-enzyme complex did not induce any negative impacts on the laying rate, egg quality traits, or antioxidant status. The partial substitution of SBM protein with SFM in Naked Neck hens' diets preserved successful efficiency and enhanced yolk color, showing that SFM was an economically viable substitute feed ingredient [20]. Earlier studies showed that the dietary SFM inclusion rates greater than 5\% required lysine supplementation. SFM has a variable content of amino acids with lysine content that ranged from $0.56 \%$ to $0.66 \%$ and methionine content of $0.33 \%$ to $0.50 \%$ [14]. Lysine supplementation to the laying hens' diets containing SFM does not appear as crucial as in broilers' diets due to lower lysine requirement. Methionine, the first limiting amino acid, restricts egg weight, egg development, and egg mass [21-23].

Furthermore, SFM has potential environmental benefits in which the dietary inclusion of $20 \%$ SFM in the laying hens' diets significantly decreased ammonia and total nitrogen emissions [24]. The high fiber content of SFM is expected to have formed more fermented substrates in the gastrointestinal tract, leading to more significant microbial proteins [24]. Additionally, feeding poultry on SFM might have an indirect environmental impact by producing volatile fatty acids (VFA), which decreases the $\mathrm{pH}$ of the manure $[25,26]$.

However, very few studies have assessed the dietary addition of SFM, as a supplier of polyunsaturated fatty acids (PUFA), in the laying hens' diets on the laying efficiency, yolk fatty acids (FA), and cholesterol concentration. Therefore, the current research is intended to assess the effect of dietary inclusion of SFM as a complementary protein resource on the laying performance, egg quality parameters, yolk fatty acids content, and nutrient digestibility of laying hens. The assumption examined was that the dietary inclusion of SFM might improve the production performance (egg production, egg mass, and feed conversion ratio), some egg quality characteristics (yolk height and yolk color), and enrich egg yolk with beneficial fatty acids (omega-3 fatty acids). 


\section{Materials and Methods}

This study was permitted by the Local Experimental Animals Care Committee's Ethics Committee and done according to the rules of Kafrelsheikh University, Egypt. (No. 4/2016EC).

\subsection{Chemical Composition of Sunflower Meal (SFM)}

Sunflower meal was provided from the Egyptian raw material market in pellet form; this was ground before use. The chemical composition values used for soybean meal (SBM) and sunflower meal (SFM) were analyzed in the laboratory of feed analysis at Kafrelsheikh University, Egypt and the values recorded by national research council (NRC) [27] and shown in Table 1. The metabolizable energy content of SBM and SFM were calculated with the following equation [27]:

$$
\text { Men }=26.7 \times \mathrm{DM}+77 \times \mathrm{EE}-51.22 \times \mathrm{CF}
$$

where:

DM: dry matter, $\%$.

EE: ether extract, \%.

CF: crude fiber, $\%$.

Table 1. Nutrient composition and metabolizable energy content of soybean meal and sunflower meal (\% DM).

\begin{tabular}{ccc}
\hline Nutrients & Soybean Meal & Sunflower Meal \\
\hline DM, $\%$ 1 & 92.06 & 91.20 \\
Crude protein, $\%$ & 46.0 & 36.00 \\
ME, kcal $/$ kg diet $^{2}$ & 2350 & 1800 \\
Calcium, \% & 0.3 & 0.40 \\
Total Phosphorus, $\%$ & 0.64 & 0.70 \\
Ether extract, \% & 1.42 & 2.87 \\
Crude fiber, $\%$ & 5.6 & 17.00 \\
Lysine, $\%$ & 3.04 & 1.50 \\
Methionine, $\%$ & 0.66 & 0.91 \\
Linolenic fatty acid, $\%$ & 3.83 & 1.97 \\
\hline
\end{tabular}

Analyzed values are mean of all replicates; ${ }^{1} \mathrm{DM}$, dry matter; ${ }^{2} \mathrm{ME}$, metabolizable energy.

\subsection{Birds, Housing, and Experimental Design}

A total of 162 Bovans laying hens, aged 60 weeks old (well beyond the laying peak and even the age at which most farms hens stop laying) with an average laying rate of $60.5 \%$, was individually housed in cages in an open-sided structure under a 16-h light system, $8 \mathrm{~h}$ of darkness with LED light colors. A light intensity of 15 lux, however, controlled the dark period by closing the windows with blackout curtains. Laying hens (started lay at 20 weeks of age) were arbitrarily allotted into three dietary groups. Each group (54 laying hens) was randomly assigned into nine replicates; each replicate had six hens caged in Big Dutchman in regular dimensions of $40 \times 35 \times 60 \mathrm{~cm}^{3}$, in a double-sided battery cage. An automated nipple drinker was given for each cage. Birds were fed, on ad libitum basis, basal diet as the control, and two levels of SFM, 50 and $100 \mathrm{~g} / \mathrm{kg}$ feed from 60 to 68 weeks of (thus from weeks 40 to 48 of laying). The composition of the experimental diets is presented in Table 2. Diets were calculated to meet the recommendations of NRC [27] for Brown Bovans laying hens. 
Table 2. Ingredients and components of the experimental diets.

\begin{tabular}{|c|c|c|c|}
\hline \multirow{2}{*}{ Ingredient } & \multicolumn{3}{|c|}{ Diets, g/kg } \\
\hline & Control & $50 \mathrm{~g} \mathrm{SFM} / \mathrm{kg}$ & $100 \mathrm{~g} \mathrm{SFM} / \mathrm{kg}$ \\
\hline Yellow corn & 635 & 650 & 605 \\
\hline Soybean meal, $46 \%$ & 240 & 108 & 109 \\
\hline Corn gluten meal, $62 \%$ & & 60 & 37 \\
\hline Soybean oil & 18 & 9 & 26 \\
\hline Di-calcium phosphate & 20 & 19 & 17.8 \\
\hline Sunflower meal, 36\% & & 50 & 100 \\
\hline Wheat bran & & 7 & 8 \\
\hline DL- methionine & 2.1 & 1.6 & 1.6 \\
\hline L-lysine & & 3.2 & 3 \\
\hline Threonine & 0.5 & 1.7 & 1.7 \\
\hline Limestone & 72 & 73.6 & 74 \\
\hline $\mathrm{NaCl}$ & 3 & 3 & 3 \\
\hline Premix * & 4 & 4 & 4 \\
\hline Sodium bicarbonate & 2.4 & 2.4 & 2.4 \\
\hline Potassium carbonate & 3 & 6.5 & 6.5 \\
\hline Choline chloride & & 1 & 1 \\
\hline Total & 1000 & 1000 & 1000 \\
\hline \multicolumn{4}{|l|}{ Calculated analysis ** } \\
\hline Crude protein, \% & 16.09 & 16.02 & 15.99 \\
\hline ME (kcal/kg diet) & 2851 & 2850 & 2850 \\
\hline Calcium, \% & 3.26 & 3.29 & 3.29 \\
\hline Total phosphorus, \% & 0.71 & 0.70 & 0.71 \\
\hline Available phosphorus, $\%$ & 0.46 & 0.46 & 0.47 \\
\hline Ether extract, $\%$ & 4.46 & 3.68 & 5.12 \\
\hline Fiber, $\%$ & 2.80 & 3.15 & 3.86 \\
\hline Lysine, \% & 0.88 & 0.89 & 0.89 \\
\hline Methionine, \% & 0.49 & 0.51 & 0.51 \\
\hline \multicolumn{4}{|l|}{ Chemical analysis } \\
\hline Moisture, $\%$ & 11.27 & 11.31 & 11.29 \\
\hline Crude protein, $\%$ & 16.11 & 16.19 & 16.03 \\
\hline Ether extract, \% & 4.51 & 3.93 & 4.98 \\
\hline Fiber, $\%$ & 2.93 & 3.22 & 3.97 \\
\hline Calcium, $\%$ & 3.30 & 3.28 & 3.27 \\
\hline Total phosphorus, $\%$ & 0.68 & 0.69 & 0.69 \\
\hline
\end{tabular}

* Premix composition (units per kilogram of feed): vitamin $A, 10,000$ IU; vitamin $D_{3}, 3,500$ IU; vitamin E, 35 IU; menadione, $1.5 \mathrm{mg}$; vitamin $\mathrm{B}_{1}, 1.5 \mathrm{mg}$; vitamin $\mathrm{B}_{2}, 5 \mathrm{mg}$; vitamin $\mathrm{B}_{5}, 8 \mathrm{mg}$; vitamin $\mathrm{B}_{6}, 1.5 \mathrm{mg}$; vitamin $\mathrm{B}_{12}$ $0.012 \mathrm{mg}$; folic acid, $0.5 \mathrm{mg}$; niacin, $30 \mathrm{mg}$; biotin, $0.06 \mathrm{mg}$; iodine, $0.8 \mathrm{mg}$; $\mathrm{Cu}, 10 \mathrm{mg}$; $\mathrm{Fe}, 80 \mathrm{mg}$; $\mathrm{Se}, 0.3 \mathrm{mg}$; $\mathrm{Mn}$, $80 \mathrm{mg} ; \mathrm{Zn}, 80 \mathrm{mg}$. ${ }^{* *}$ Calculated according to NRC [27] for Brown Bovans laying hens. The diets were provided in mash form.

\subsection{Performance Parameters}

At the beginning ( 60 weeks of age) and the end ( 68 weeks of age) of the trial, the birds were weighed individually by ZIEIS Digital Bird Scale, A63SS-NMP, 0.05 Ounce Accuracy, 5000 Gram Capacity. Eggs were hoarded every day. The laying rate was calculated as hen-day (\% hens-day) by applying the following equation (number of daily eggs produced per treatment/number of birds accessible in the treatment on that day $\times 100$ ). Each egg weight was assessed and then utilized for all experimental times to evaluate the mean egg weight. The total egg mass was determined by laying rate by multiplying the weights of the eggs. As the hens were fed by an ad libitum system, the feed amount was added according to the catalog, and after seven days, the remaining feed was measured, and then the intake of feed was calculated on a cage base (a hen). Daily feed consumption per hen for all days during the trial was determined. The FCR ( $\mathrm{kg}$ of feed $/ \mathrm{kg}$ of eggs) was assessed utilizing egg production, egg weight, and feed intake. 


\subsection{Egg Quality Parameters}

Egg quality parameters including egg length, egg width, egg shape, shell thickening, high albumin, high yolk, yolk width, yolk index, and yolk color score were undertaken and measured at the beginning of the experiment (60 weeks of age) and the end of the experiment ( 68 weeks of age). From each test, 30 eggs lay between 08:00 and 12:00 h were arbitrarily selected. A digital egg scale individually weighed eggs, accurate to $1 / 10$ th of a gram, $100 \mathrm{~g}$ maximum capacity, and the egg quality estimation was done on individual eggs, likewise the egg weight. The eggs were broken on the plate measurement stand egg Quality Microprocessor (EQM), and the albumen and yolk heights were determined. Yolk color score was measured utilizing the Roche yolk color fan method (DSM Yolk Color Fan, Basel, Switzerland). Eggshell thickness was performed by determining the thickness mean values taken at three locations on the egg (air cell, equator, and sharp end) utilizing a micrometer caliper (Mitutoyo, 0.01 to $20 \mathrm{~mm}$, Tokyo, Japan).

\subsection{Yolk Fatty Acid Content, Total Cholesterol, Vitamin E, and Ca Concentrations}

At the beginning of the experiment (60 weeks) and the end (68 weeks), 30 eggs were collected per procedure to measure the content of FAs in the egg yolk, including myristic, palmitic, palmitoleic, stearic, oleic, veccenic, linoleic, linolenic, arachidonic, Eicosapentaenoic acid (EPA), Docosapentaenoic acid (DPA), Docosahexaenoic acid (DHA), yolk fat and total cholesterol. Analysis of the previous fatty acids was performed using a Shimadzu GC-4 CM (PFE) gas chromatograph fitted with a flame ionization detector (FID).

Before running the samples, a regular blend of methyl esters was examined under similar circumstances. The retention times of the unidentified methyl ester sample were compared with those of the standard. In the triangulation process, the quantity of methyl esters was assessed according to Radwan [28] and Saleh et al. [29].

Fatty acids were expressed as $\mathrm{mg} / 100 \mathrm{~g}$ fat. For determination of vitamin $\mathrm{E}$ and Ca in the egg yolk, pooled samples were homogenized in a $0.054 \mathrm{~mol} / \mathrm{L}$ dibasic sodium phosphate buffer amended to $7 \mathrm{pH}$ with $\mathrm{HCl}$. After being mixed with absolute ethanol and hexane, the upper layer $\alpha$-T was evaporated and dissolved in ethanol before evaluation by HPLC3 (UV detector fixed at $290 \mathrm{~nm}$ ). Egg yolk total cholesterol was measured through the extraction of fat from the egg yolk with chloroform and methanol admixture (2:1 vol:vol) methods according to Surai [30] and expressed as $\mathrm{mg} / 100 \mathrm{~g}$ fat.

Calculation of the lipid quality indices including the atherogenic index (AI) and the thrombogenic index (TI) were performed following Ulbricht and Southgate [31]. The peroxidability index (PI) was assessed using the equation of Arakawa and Sagai [32].

\subsection{Nutrient Digestibility}

For digestibility tests, excreta were collected and weighted from each cage replicate over the last three days of the experiment. The feed intake and birds were weighted daily during these three days, and feces eliminated were collected, weighed, and placed in a freezer. Following the digestibility trial, all samples were dried in a drying oven at $60{ }^{\circ} \mathrm{C}$ for $24 \mathrm{~h}$. Next, the whole dried samples were homogenized according to AOAC [33] and finely ground for examination. The crude protein substance in the diet and excreta was determined using the Kjeldahl method to determine the digestibility of nitrogen $(\mathrm{CP}$, Method 968.06), the fat extract was calculated using the Soxhlet method (EE, Method920.39), crude fiber (CF, Method 932.09) and calcium (Ca, Method 985.35). The calculation was as follows:

Nitrogen digestibility $(\%)=($ total nitrogen intake - total nitrogen excreted $) /$ total nitrogen intake $\times 100$.

\subsection{Statistical Analysis}

Statistically, the experimental results were analyzed using a one-way analysis of variance (ANOVA) (IBM SPSS Statistics Version 25.0. Armonk, NY, USA: IBM Corp). We 
contrasted the means of different treatments using Duncan's new multiple range test. The limit of significance was at $p<0.05$.

\section{Results}

\subsection{Laying Performance}

Table 3 presents the impact of feeding SFM on the efficiency parameters of laying birds. Non-significant changes in final body weight, body weight gain, feed intake, egg weight, and egg mass were observed among the dietary groups. An increase in egg production $(p<0.05)$ was noted in laying hens fed the SFM diets compared with those fed the control diet. The percent of broken eggs was the lowest from laying hens-fed SFM $(p<0.05)$. Laying hens fed the SFM diets had better FCR $(p<0.05)$ when controlling the control one.

Table 3. Effect of feeding sunflower meal (SFM) on the production performance of laying hens.

\begin{tabular}{|c|c|c|c|c|c|}
\hline Item & Control & $\begin{array}{l}\text { erimental Die } \\
50 \mathrm{~g} \mathrm{SFM} / \mathrm{kg}\end{array}$ & $100 \mathrm{~g} \mathrm{SFM} / \mathrm{kg}$ & SEM & $p$-Value \\
\hline $\begin{array}{l}\text { Initial body weight (60 } \\
\text { wks.), g }\end{array}$ & 1512.8 & 1516.1 & 1516.1 & 37.11 & 0.99 \\
\hline $\begin{array}{c}\text { Final body weight, (68 } \\
\text { wks.), g }\end{array}$ & 1586.5 & 1587.2 & 1588.8 & 37.35 & 0.99 \\
\hline Body weight gain, g & 73.8 & 71.1 & 72.6 & 1.42 & 0.75 \\
\hline Feed intake, g/day & 116.6 & 116.5 & 116.4 & 0.39 & 0.98 \\
\hline Egg production, \% & $61.7^{b}$ & $65.0^{\mathrm{a}}$ & $65.4^{\mathrm{a}}$ & 0.04 & 0.05 \\
\hline Egg weight, g & 55.8 & 58.2 & 58.7 & 0.58 & 0.12 \\
\hline $\begin{array}{l}\text { Egg mass, g of } \\
\text { egg/hen/day }\end{array}$ & 34.4 & 37.8 & 38.4 & 0.49 & 0.09 \\
\hline FCR, $g$ feed/g egg & $3.39^{b}$ & $3.08^{a, b}$ & $3.03^{\mathrm{a}}$ & 0.06 & 0.05 \\
\hline Broken egg, \% & $11.4^{\mathrm{a}}$ & $9.9^{b}$ & $8.9^{\mathrm{b}}$ & 0.26 & 0.05 \\
\hline
\end{tabular}

Values are presented as means $\pm \mathrm{SE}$ of 60 per group. ${ }^{\mathrm{a}, \mathrm{b}}$ Mean values with different superscripts in the same row are different at $p<0.05$. $\mathrm{FCR}=$ feed conversion ratio.

\subsection{Selected Egg Characteristics}

The effect of feeding SFM on the selected egg characteristics at the beginning of the experiment ( 60 weeks of age) and the end of the experiment (68 weeks of age) is presented in Table 4. There was a non-substantial impact $(p<0.05)$ of the SFM levels on the egg quality characteristics, except for yolk color score and yolk height, which were higher $(p=0.01)$ for laying hens fed SFM concerning hens fed control.

Table 4. Impact of feeding SFM on the selected egg characteristics of laying hens.

\begin{tabular}{|c|c|c|c|c|c|}
\hline Item & Control & $\begin{array}{l}\text { Experimental Diets } \\
50 \mathrm{~g} \mathrm{SFM} / \mathrm{kg}\end{array}$ & $100 \mathrm{~g} \mathrm{SFM} / \mathrm{kg}$ & SEM & $p$-Value \\
\hline \multicolumn{6}{|c|}{ At week 40 of laying (60 wk of age) } \\
\hline Egg length, cm & 5.92 & 5.99 & 5.99 & 0.034 & 0.64 \\
\hline Egg width, cm & 4.46 & 4.41 & 4.42 & 0.024 & 0.65 \\
\hline Egg shape index, \% & 75.33 & 73.62 & 73.79 & 0.005 & 0.29 \\
\hline Eggshell thickness, $\mu \mathrm{m}$ & 327.9 & 328.6 & 328.9 & 4.06 & 0.19 \\
\hline Albumen height, cm & 0.85 & 0.85 & 0.84 & 0.024 & 0.93 \\
\hline Yolk height, cm & 2.03 & 2.03 & 2.04 & 0.016 & 0.89 \\
\hline Yolk width, cm & 4.48 & 4.5 & 4.49 & 0.031 & 0.86 \\
\hline Yolk index, \% & 45.31 & 45.11 & 45.43 & 0.004 & 0.95 \\
\hline Yolk color score & 6.7 & 6.7 & 6.7 & 0.13 & 0.99 \\
\hline \multicolumn{6}{|c|}{ At week 48 of laying ( $68 \mathrm{wk}$ of age) } \\
\hline Egg length, $\mathrm{cm}$ & 5.85 & 5.93 & 6.41 & 1.17 & 0.36 \\
\hline Egg width, cm & 4.44 & 4.47 & 4.46 & 0.028 & 0.89 \\
\hline Egg shape index, \% & 75.89 & 75.38 & 69.58 & 0.015 & 0.40 \\
\hline Eggshell thickness, $\mu \mathrm{m}$ & 320.8 & 323.7 & 335.4 & 4.29 & 0.34 \\
\hline
\end{tabular}


Table 4. Cont.

\begin{tabular}{cccccc}
\hline Item & Control & $\begin{array}{c}\text { Experimental Diets } \\
\mathbf{5 0} \mathbf{~ g F M / k g}\end{array}$ & $\mathbf{1 0 0} \mathbf{~ g ~ S F M / k g}$ & SEM & $p$-Value \\
\hline Albumen height, cm & 0.75 & 0.80 & 0.73 & 0.013 & 0.11 \\
Yolk height, cm & $1.83^{\mathrm{b}}$ & $2.13^{\mathrm{a}}$ & $2.22^{\mathrm{a}}$ & 0.056 & 0.01 \\
Yolk width, cm & 4.51 & 4.46 & 4.52 & 0.027 & 0.63 \\
Yolk index, $\%$ & 40.57 & 47.75 & 49.11 & 0.004 & 0.16 \\
Yolk color score & $6.6^{\mathrm{b}}$ & $7.8^{\mathrm{a}}$ & $7.9^{\mathrm{a}}$ & 0.145 & 0.01 \\
\hline
\end{tabular}

Values are presented as means of 30 eggs per group and SEM for a total of 90 eggs from three study groups. ${ }^{a, b}$ Mean values with distinct superscripts in the same row are different at $p<0.05$.

\subsection{Yolk Fat, Fatty Acid (FA) Content, Vitamin E, and Ca Contents in the Egg Yolk}

Results concerning the effects of feeding SFM on egg yolk nutritional analysis in laying hens are shown in Table 5. The addition of SFM in the diets of laying hens did not influence the egg yolk fat content; however, it increased $(p<0.05)$ linoleic acid, linolenic acid, and oleic acid egg yolk content. On the other hand, palmitic acid's egg yolk concentration was decreased significantly by feeding SFM. Myristic, palmitoleic, stearic, vaccenic, arachidonic, eicosapentenoic, docosapentenoic, docosahexenoic acids AI, TI, and PI was not substantially affected by the dietary treatments. However, all fatty acids were not influenced at the beginning of the experiment. Interestingly, cholesterol level was significantly lowered by dietary treatments $(p<0.05)$.

Table 5. Effect of feeding SFM on the egg yolk fatty acid composition (\%) of laying hens.

\begin{tabular}{|c|c|c|c|c|c|}
\hline \multirow{2}{*}{ Item } & \multicolumn{3}{|c|}{ Experimental Diets } & \multirow[t]{2}{*}{ SEM } & \multirow[t]{2}{*}{$p$-Value } \\
\hline & Control & $50 \mathrm{~g} \mathrm{FM} / \mathrm{kg}$ & $100 \mathrm{~g} \mathrm{FM} / \mathrm{kg}$ & & \\
\hline \multicolumn{6}{|c|}{ At start (week 40 of laying) } \\
\hline Myristic acid (C14:0) & 0.23 & 0.22 & 0.23 & 0.02 & 0.63 \\
\hline Palmitic acid (C16:0) & 24.5 & 24.52 & 24.45 & 0.62 & 0.75 \\
\hline Palmitoleic acid (C16:1) & 2.78 & 2.77 & 2.93 & 0.23 & 0.62 \\
\hline Stearic acid (C18:0) & 8.95 & 8.97 & 8.82 & 0.33 & 0.88 \\
\hline Oleic acid (C18:1 n-9c) & 43.2 & 42.98 & 43.11 & 2.65 & 0.72 \\
\hline Vaccenic acid (C18:1 n-7) & 1.95 & 1.92 & 1.94 & 0.21 & 0.81 \\
\hline Linoleic acid (C18:2 n-6) & 14.44 & 14.62 & 14.51 & 0.92 & 0.58 \\
\hline Linolenic acid (ALA, C18:3 n-3) & 0.52 & 0.53 & 0.56 & 0.032 & 0.41 \\
\hline Arachidonic acid (AA, C20:4 n-6) & 1.81 & 1.91 & 1.81 & 0.091 & 0.42 \\
\hline Eicosapentenoic acid (EPA, C20:5 n-3) & 0.088 & nd & 0.088 & 0.0001 & 0.82 \\
\hline Docosapentenoic acid (DPA, C22:5n-3) & 0.111 & 0.111 & 0.112 & 0.001 & 0.64 \\
\hline Docosahexenoic acid (DHA, C22:6n-3) & 0.867 & 0.866 & 0.869 & 0.002 & 0.34 \\
\hline $\mathrm{AI}$ & 0.436 & 0.438 & 0.438 & 0.00611 & 0.98 \\
\hline $\mathrm{TI}$, & 0.932 & 0.931 & 0.931 & 0.00685 & 0.98 \\
\hline PI, & 24.233 & 24.233 & 24.239 & 0.1147 & 1.00 \\
\hline \multicolumn{6}{|c|}{ After 8 weeks of the experiment (week 48 of laying) } \\
\hline Myristic acid (C14:0) & 0.22 & 0.23 & 0.24 & 0.021 & 0.57 \\
\hline Palmitic acid (C16:0) & $26.8^{a}$ & $23.11^{\mathrm{a}, \mathrm{b}}$ & $20.07^{\mathrm{b}}$ & 1.42 & 0.042 \\
\hline Palmitoleic acid (C16:1) & 2.94 & 2.58 & 2.32 & 0.36 & 0.37 \\
\hline Stearic acid (C18:0) & 7.66 & 7.32 & 7.14 & 0.28 & 0.48 \\
\hline Oleic acid (C18:1 n-9c) & $42.54^{\mathrm{b}}$ & $45.28^{a}$ & $47.12^{\mathrm{a}}$ & 3.12 & 0.045 \\
\hline Vaccenic acid (C18:1 n-7) & 1.94 & 1.93 & 1.93 & 0.23 & 0.79 \\
\hline Linoleic acid (C18:2 n-6) & $14.34^{\mathrm{b}}$ & $15.51^{\mathrm{a}, \mathrm{b}}$ & $17.45^{\mathrm{a}}$ & 1.01 & 0.048 \\
\hline Linolenic acid (ALA, C18:3 n-3) & $0.42^{b}$ & $0.52^{\mathrm{a}}$ & $0.56^{\mathrm{a}}$ & 0.052 & 0.042 \\
\hline Arachidonic acid (AA, C20:4 n-6) & 1.8 & 1.8 & 1.79 & 0.092 & 0.92 \\
\hline Eicosapentenoic acid (EPA, C20:5 n-3) & 0 & 0.027 & 0.028 & 0.00008 & - \\
\hline Docosapentenoic acid (DPA, C22:5n-3) & 0.115 & 0.114 & 0.114 & 0.001 & 0.72 \\
\hline Docosahexenoic acid (DHA, C22:6n-3) & 0.875 & 0.873 & 0.872 & 0.002 & 0.68 \\
\hline
\end{tabular}


Table 5. Cont.

\begin{tabular}{cccccc}
\hline Item & \multicolumn{2}{c}{ Experimental Diets } & SEM & p-Value \\
& Control & $\mathbf{5 0} \mathbf{g}$ FM/kg & $\mathbf{1 0 0} \mathbf{g}$ FM/kg & & \\
\hline AI, & 0.427 & 0.422 & 0.421 & 0.00583 & 0.74 \\
TI, & 0.953 & 0.963 & 0.963 & 0.0145 & 0.86 \\
PI, & 24.495 & 24.501 & 24.783 & 0.2389 & 0.65 \\
Yolk fat, g/100 g yolk & 28.76 & 29.11 & 29.21 & 2.19 & 0.58 \\
Total Cholesterol, mg/100 g yolk & $137.07^{\mathrm{a}}$ & $130.60^{\mathrm{a}, \mathrm{b}}$ & $122.47^{\mathrm{b}}$ & 2.45 & 0.04 \\
\hline
\end{tabular}

Values are presented as means of 15 samples per treatment and SEM for 45 samples from all study groups; for “a,b Mean values with different superscripts in the same row are different at $p<0.05$. nd $=$ not detected.

The vitamin E and Ca contents in the egg yolk of laying hens fed the experimental diets were demonstrated in Table 6. Inclusion of SFM in the diets of laying hens increased $(p<0.05)$ vitamin $\mathrm{E}$ and Ca contents in the egg yolk.

Table 6. Effect of feeding SFM on vitamin E and calcium contents in egg yolk of laying hens at the end of the experiment.

\begin{tabular}{cccccc}
\hline \multirow{2}{*}{ Item } & \multicolumn{3}{c}{ Experimental Diets } & SEM & \multirow{2}{*}{-Value } \\
& Control & $\mathbf{5 0} \mathbf{~ g ~ S F M / k g}$ & $\mathbf{1 0 0} \mathbf{~ g ~ S M / k g ~}$ & & \\
\hline $\begin{array}{c}\text { Vitamin E, mg/100 g } \\
\text { Calcium content, } \\
\text { mg/100 g }\end{array}$ & $5.11^{\mathrm{b}}$ & $5.60^{\mathrm{a}, \mathrm{b}}$ & $6.10^{\mathrm{a}}$ & 0.0116 & 0.01 \\
\hline
\end{tabular}

Values are presented as means \pm SE of 15 samples per group. ${ }^{\text {a,b }}$ Mean values with different superscripts in the same row are different at $p<0.05$.

\subsection{Nutrient Digestibility}

Table 7 reveals the effect of feeding SFM on nutrient digestibility in laying hens. The dietary treatments significantly increased the rate of $\mathrm{CP}(p=0.01)$ and $\mathrm{Ca}(p=0.05)$ digestibility. Interestingly, the addition of SFM in laying hens diets significantly decreased the digestibility of laying hens to $\operatorname{EE}(p=0.05)$.

Table 7. Effect of feeding SFM on nutrient digestibility of laying hens at the end of the experiment.

\begin{tabular}{|c|c|c|c|c|c|}
\hline \multirow{2}{*}{ Item } & \multicolumn{3}{|c|}{ Experimental Diets } & \multirow[t]{2}{*}{ SEM } & \multirow[t]{2}{*}{$p$-Value } \\
\hline & Control & $\begin{array}{c}50 \mathrm{~g} \\
\mathrm{SFM} / \mathrm{kg}\end{array}$ & $100 \mathrm{~g} \mathrm{SFM} / \mathrm{kg}$ & & \\
\hline Crude protein, $\%$ & $66.1^{b}$ & $68.1^{\mathrm{a}}$ & $68.0^{\mathrm{a}}$ & 0.375 & 0.01 \\
\hline Crude fiber, $\%$ & 33.3 & 36.3 & 35.2 & 0.633 & 0.15 \\
\hline Ether Extract, \% & $25.8^{\mathrm{a}}$ & $25.0^{a, b}$ & $24.1^{\mathrm{b}}$ & 0.322 & 0.05 \\
\hline Calcium, \% & $32.3^{b}$ & $36.0^{a, b}$ & $37.1^{\mathrm{a}}$ & 0.911 & 0.05 \\
\hline Phosphorous, \% & 29.9 & 36.0 & 34.7 & 1.406 & 0.18 \\
\hline
\end{tabular}

Values are presented as means of 15 samples per treatment and SEM for 45 samples from all study groups; for ${ }^{\mathrm{a}, \mathrm{b}}$ Mean values with different superscripts in the same row are different at $p<0.05$.

However, non-significant differences were detected in the CF and P digestibility between the dietary treatments.

\section{Discussion}

As the world's population grows, demand for eggs will continue to rise. To meet this demand sustainably will be a big challenge because of the traditional plant protein sources' high cost for layer hens diets. Furthermore, poultry nutritionists have been working for decades on sustainability in higher egg production. Using alternative plant protein sources like sunflower seed meal and others are innovative solutions for reducing the cost of the diets and improving the production, leading to the production and improvement of the environment. 


\subsection{Laying Performance}

The current study's findings showed that feeding SFM significantly improved laying performance, broken egg ratio, and FCR for laying hens at a very late phase of laying (phase 2 of the production).

The available findings of the probable impacts of dietary inclusion of SFM on laying efficiency and FCR are questionable and contrasting. Several earlier studies have revealed that dietary inclusion of SFM had no adverse effect on live weight, feed intake, egg production, or FCR $[2,7,8,15]$. In contrast, other studies [4-6,14,34] showed that supplementation of SFM in the laying hens' diets improved the laying performance and FCR.

Additionally, Sunil [35] found a substantial increase in the rate of laying and FCR when SFM was incorporated in the diet at a concentration of $13 \%$ and attained maximum benefit. Due to the upsurge in the layer's body mass, body mass constancy in laying bird diets containing various protein resources can enhance laying performance [36].

Considering egg production percent and feed intake, FCR determination is possibly the largest single variable used in laying hens' economic assessments for the laying rate [37].

Additionally, the egg weight among experimental hens, was statistically similar. The average egg weight was also variable and compared favorably with laying hens' values recorded in the available literature [2,38]. For normal digestive function, a significant amount of fiber is needed. However, ingredients with high fiber content are limited in poultry diets due to their low energy content. The appropriate amount of crude dietary fiber in a realistic laying hen diet is between 35 and $45 \mathrm{~g} / \mathrm{kg}$ [2]. Based on the dehulling degree, the rudimentary fiber of SFM seems to be the most critical component of poultry diets [39]. The enhancement in the laying performance of hens in the present trial might be ascribed to the use of high-protein and low-fiber SFM, and the added lysine contributes to the improved feed intake of laying hens. Seidavi et al. [9] indicated that SFM might be effectively included in the diets of laying hens up to $40 \%$ with an increase in egg production.

\subsection{Egg Quality Parameters}

In the present study, feeding SFM to laying hens did not influence the egg quality parameters. These results are inconsistent with Shi et al. [2], Baghban-Kanani et al. [8], Tsuzuki et al. [14], and Koçer et al. [16], who described non-substantial changes in the egg quality traits when laying birds were fed various dietary SFM levels. Meanwhile, dietary SFM supplementation substantially increased the yolk height and yolk color score. These results are close to Laudadio et al. [7], who observed that the egg yolk color record was improved when SFM with low fiber content was included in the layer diet concerning the SBM treatment layers. The effect of low-fiber SFM noted in our experiment on yolk color score may be linked to the number of natural pigments found in SFM. Previous studies $[36,40]$ have shown an enhancement in yolk color as leguminous plant levels increased in the diets of laying hens.

On the other hand, adding dietary fat is essential as it accelerates the absorption of pigment and fat-soluble vitamins [41]. De Morais Oliveira et al. [20] indicated that the amount of lipids in the SFM diet augmented pigment absorption, resulting in improved yolk color. In contrast, Shi et al. [2] and Tsuzuki et al. [14] described no positive effect of dietary SFM on the egg yolk color.

\subsection{Yolk Fat, Fatty Acids, Vitamin E, and Calcium Contents in Egg Yolk}

The dietary addition of SFM, in the current study, increased the egg yolk contents of linoleic acid, $\alpha$-linolenic acid, oleic acid, vitamin E, and Ca. Unsaturated FA plays a vital role in animal and human nutrition as they minimize metabolic problems such as cardiovascular diseases and diabetes [42]. It is commonly identified that sunflower is a good source of FA. In contrast, for high oleic sunflower oil, the reported contents for palmitic, stearic, linoleic, and oleic acids were $4.6 \%, 3.4 \%, 27.5 \%$, and $62.8 \%$, respectively. For ordinary sunflower oil, these values were $6.2 \%, 3.7 \%, 25.2 \%$, and $63.1 \%$, correspondingly [43]. Laudadio et al. [7] stated that substitution of SBM with SFM in layer diets did 
not cause any adverse impacts on egg production and egg quality, but modified the lipids contained in the yolk.

Comparably, Ebeid et al. [44] indicated that the increased $\alpha$-linolenic acid in the eggs of laying hens might be achieved by introducing specific resources to the diets of laying hens like seed meals or oil sources. Additionally, sunflower seeds are exceptionally rich in $\alpha$-tocopherols (608 $\mathrm{mg} / \mathrm{kg}$ seed), which perform as potent antioxidants. Therefore, sunflower is believed to be a higher source of vitamin E. Nevertheless, heat inactivation of $\alpha$-tocopherols is easier than $\mathrm{p}$ - and y-tocopherols, which are more common in soybean and cotton oil [45]. Furthermore, the protein obtained from SFM has a well-balanced composition of amino acids. SFM is considered a healthy source of $\mathrm{Ca}, \mathrm{P}$, and vitamin B-complex [46]. Our findings demonstrated that the inclusion of SFM in the diets of laying birds reduced the content of egg yolk cholesterol. Such results agreed with several previous studies $[2,7,8]$, which recorded a substantial decrease in the egg yolk cholesterol when replacing SBM with SFM. This appears to appeal to consumers, as one of the primary health threat considerations associated with cardiac troubles is a higher circulating cholesterol level [47]. The hypo-cholesterolemic influence in serum and egg yolk of low-fiber SFM may be partially by diminishing the hepatic de novo lipogenesis.

Nevertheless, it is unidentified if SFM supplementation is efficient in decreasing the intestinal absorption of biliary cholesterol of laying hens, which regulates the whole-body cholesterol to reduce the cholesterol content in blood and egg yolk [47]. Additionally, a decrease in the yolk cholesterol content resulting from feeding low-fiber SFM may be partially due to the plant sterols present in sunflower with a hypo-cholesterolemic impact [48]. On the other hand, fiber's role in lowering cholesterol may be beneficial with the inclusion of SFM in the poultry diet. One possible mechanism in which SFM can perform its hypo-cholesterolemic effect is through bile acids. The cholic and deoxycholic bile acids are formed by hepatocytes from cholesterol and are conjugated with glycine and taurine correspondingly.

\subsection{Nutrient Digestibility}

In the present study, the substantial rise in the digestibility of $\mathrm{CP}$ and $\mathrm{Ca}$ in laying hens fed the SFM diets was an indication that these diets have met the birds' requirements and may have been caused by the reduction of anti-nutritional factors in the used SFM. Since sunflower has characteristics such as chlorogenic acid, which inhibits trypsin activity by $30 \%$, the levels of chlorogenic acid of $40 \mathrm{~g} / \mathrm{kg}$ in the sunflower seeds may have been enough to decrease the digestibility of the dietary protein. Consequently, the response to additional lysine, where about $43 \%$ of the chlorogenic acid was destroyed by heating at $100{ }^{\circ} \mathrm{C}$ or $135^{\circ} \mathrm{C}$ for $5 \mathrm{~h}$.

On the other hand, similar to soybean, cotton, and rapeseed meals, one advantage of SFM is that it does not include large levels of anti-nutritional factors [49,50]. Bedford and Classen [51] reported that the SFM content of raw fibers might be three times greater than SBM. The fibers' quantity, which originates from the cortex, is considered highly resistant to bacterial dilapidation in the gastrointestinal tract. This problem can be overcome by lowering the fiber content of SFM. Some promising findings have been recorded when meals are heat-treated [37], ground with pins [52], or air-classified [53,54]. Furthermore, laying hens have a more evolved digestive system than broilers in gut ability [15].

On the other hand, variations in complexity, chemical composition, treatment method, fusion levels, age of birds, and food preparation methods used in various studies may explain not always obtaining consistent results. Despite some contradictory findings, previous studies have observed that SFM is deemed a great supplier of protein in poultry diets to guarantee optimum poultry production [55]. Other considerations must also be considered including low fiber ratios, pelleting the feed, using oils, supplementing lysine, measuring protein solubility, and adding enzymes that suit the SFM NSP content to improve feed performance. Thus, further research regarding SFM quality factors that affect the digestibility of nutrients in laying hens should be investigated [56-59]. 


\section{Conclusions}

Increasing the dietary supplement level of SFM from $50 \mathrm{~g} / \mathrm{kg}$ to $100 \mathrm{~g} / \mathrm{kg}$ did not adversely impact body weight gain, feed intake, and egg mass. The dietary inclusion of SFM improved egg production, FCR, broken eggs rate, yolk color score, and yolk height of the laying hens. Dietary supplementation with SFM decreased egg yolk cholesterol, whereas vitamin E, Ca, linoleic acid, linolenic acid, and oleic acid contents in the egg yolk were increased. Furthermore, the addition of SFM in the diets of laying hens improved $\mathrm{CP}$ and Ca digestibility, but decreased the EE digestibility. Our results suggest that the inclusion of SFM, up to $100 \mathrm{tableg} / \mathrm{kg}$, in the diets of laying bird at a late phase of laying could improve the production performance, selected egg characteristics, yolk linolenic acid, and oleic acid contents, and nutrient digestibility while decreasing egg yolk cholesterol.

Author Contributions: Conceptualization, A.A.S., A.E.-A., K.A., M.S., Y.Z.E. and M.H.A.; Methodology, A.A.S., A.E.-A., K.A., M.S., Y.Z.E. and M.H.A.; Software, S.S., M.M.S.; Validation, A.A.S., A.E.-A., K.A., Y.Z.E., M.H.A., S.S. and M.M.S.; Formal analysis, A.A.S., A.E.-A., K.A., Y.Z.E., M.H.A., S.S. and M.M.S.; Investigation, A.A.S., A.E.-A., K.A., Y.Z.E., M.H.A., S.S. and M.M.S.; Resources, A.A.S., A.E.-A., K.A., M.S., Y.Z.E. and M.H.A.; Data curation, S.S. and M.M.S.; Writing-original draft preparation, A.A.S., A.E.-A., K.A., Y.Z.E., M.H.A., M.S. and S.S.; Writing-review and editing, A.A.S., A.E.-A., K.A., Y.Z.E., M.H.A., S.S., M.S. and M.M.S. All authors have read and agreed to the published version of the manuscript.

Funding: The current work was funded by Taif University Researchers Supporting Project number TURSP-2020/09, Taif University, Taif, Saudi Arabia.

Institutional Review Board Statement: This study was declared by the Local Experimental Animals Care Committee's Ethics Committee and done according to the rules of Kafrelsheikh University, Egypt. (No. 4/2016EC).

Informed Consent Statement: Not applicable.

Data Availability Statement: All data sets collected and analyzed during the current study are available on request from the corresponding author.

Acknowledgments: We would like to thank Taif University Researchers Supporting Project number (TURSP—2020/09), Taif University, Taif, Saudi Arabia.

Conflicts of Interest: The authors declare no conflict of interest.

\section{References}

1. Alagawany, M.; Farag, M.; Abd-El-Hack, M.; Dhama, K. The practical application of sunflower meal in poultry nutrition. Adv. Anim. Vet. Sci. 2015, 3, 634-648. [CrossRef]

2. Shi, S.; Tong, H.; Zou, J. Effects of graded replacement of soybean meal by sunflower seed meal in laying hen diets on hen performance, egg quality, egg fatty acid composition, and cholesterol content. J. Appl. Poult. Res. 2010, 21, 367-374. [CrossRef]

3. Tüzün, A.; Olgun, O.; Yildiz, O. Effect of different dietary inclusion levels of sunflower meal and multi-enzyme supplementation on performance, meat yield, ileum histomorphology, and pancreatic enzyme activities in growing quails. Animals 2020, 10, 680. [CrossRef]

4. Laudadio, V.; Bastoni, E.; Introna, M. Production of low-fiber sunflower (Helianthus annuus L.) meal by micronization and air classification processes. CyTA-J. Food 2013, 11, 398-403. [CrossRef]

5. Laudadio, V.; Interona, M.; Lasstella, N.; Tufarelli, V. Feeding of low-fibre sunflower (Helianthus annus L.) meal as substitute of soybean meal in turkey rations: Effects on growth performance and meat quality. J. Poult. Sci. 2013, 62, 130-132. [CrossRef]

6. Vierira, S.; Penz, A.; Leboute, M.; Corteline, J. A nutritional evaluation of a high fiber sunflower meal. J. Appl. Poult. Res. 1992, 1, 382-388. [CrossRef]

7. Laudadio, V.; Ceci, E.; Lasstella, N.; Tufarelli, V. Effect of feeding low-fiber fraction of air-classified sunflower (Helianthus annus L.) meal on laying hen productive performance and egg yolk cholesterol. Poult. Sci. 2014, 93, 2864-2869. [CrossRef] [PubMed]

8. Baghban-Kanani, P.; Hossenintabar, B.; Azimi, Y.; Seidavi, T.; Laudadio, V.; Tufarelli, V. Effect of different levels of sunflower meal and multi-enzyme complex on performance, biochemical parameters and antioxidant status of laying hens. S. Afr. J. Anim. Sci. 2018, 48, 390-399. [CrossRef]

9. Seidavi, A.; Azizi, M.; Laudadio, V. Practical applications of agricultural wastes in poultry feeding in Mediterranean and Middle East regions. Part 2: Tomato, olive, date, sunflower wastes. World's Poult. Sci. J. 2018, 74, 443-452. [CrossRef] 
10. Azizi, M.; Sedavi, A.; Ragni, M.; Laudadio, V.; Tufarelli, V. Practical applications of agricultural wastes in poultry feeding in Mediterranean and Middle East regions. Part 1: Citrus, grape, pomegranate and apple wastes. World's Poult. Sci. J. 2018, 74, 489-498. [CrossRef]

11. Garcia-Moreno, M.; Fernandez, M.; Velasco, L.; Perez-Vich, B. Genetic basis of unstable expression of high gamma-tocopherol content in sunflower seeds. BMC Plant Biol. 2012, 12, 71. [CrossRef] [PubMed]

12. González-Pérez, S.; Vereijken, M. Sunflower proteins: Overview of their physicochemical, structural and functional properties. J. Sci. Food Agri. 2007, 87, 2173-2191. [CrossRef]

13. Manamperi, W.; Wiwswnborn, P.; Chang, K. Effects of protein separation conditions on the functional and thermal properties of canola protein isolates. J. Food Sci. 2011, 76, 266-273. [CrossRef] [PubMed]

14. Tsuzuki, E.; Garcia, M.; Murankami, A. Utilization of sunflower seed in laying hen rations. Braz. J. Poult. Sci. 2003, 5, 179-182. [CrossRef]

15. Casartelli, E.; Filardi, R.; Junqueira, O. Sunflower meal in commercial layer diets formulated on total and digestible amino acids basis. Braz. J. Poult. Sci. 2006, 8, 167-171. [CrossRef]

16. Koçer, B.; Bozkurt, M.; Ege, G.; Tüzün, A.E. Effects of sunflower meal supplementation in the diet on productive performance, egg quality and gastrointestinal tract traits of laying hens. Br. Poult. Sci. 2020. [CrossRef]

17. San, J.; Villamide, M. Nutritional evaluation of sunflower products for poultry as affected by the oil extraction process. Poult. Sci. 2001, 80, 431-437. [CrossRef]

18. Ditta, Y.; King, A. Recent advances in sunflower seed meal as an alternate source of protein in broilers. World's Poult. Sci. J. 2017, 73, 527-542. [CrossRef]

19. Fafiolu, A.; Oduguwa, O.; Jegede, A. Assessment of enzyme supplementation on growth performance and apparent nutrient digestibility in diets containing undecorticated sunflower seed meal in layer chicks. Poult. Sci. 2015, 94, 1917-1922. [CrossRef]

20. De Morais Oliveira, V.R.; Arruda, V.; Silva, J.; Souza, J. Sunflower meal as a nutritional and economically viable substitute for soybean meal in diets for free-range laying hens. Anim. Feed Sci. Technol. 2016, 220, 103-108. [CrossRef]

21. Elliot, M.A. Amino acid nutrition of commercial pullets and layers. In Proceedings of the Dairy Nutritional Strategies to Meet Economic and Environmental Challenges, Salt Lake City, UT, USA, 29-30 January 2008; p. 193. [CrossRef]

22. Saleh, A.A. Effects of fish oils on the production performances and polyunsaturated fatty acids and cholesterol levels of yolk in hens. Emir. J. Food Agric. 2013, 25, 605-612. [CrossRef]

23. Saleh, A.A. Effect of Low-Protein in Iso-Energetic Diets on Performance, Carcass Characteristics, Digestibilities and Plasma Lipids of Broiler Chickens. Egypt. Poult. Sci. J. 2016, 36, 251-262. [CrossRef]

24. Naseem, S.; King, A.J. Effects of multi-species lactobacillus and sunflower seed meal on nitrogen-containing compounds in laying hens' manure and biological components in blood serum. J. Appl. Poult. Res. 2020, 29, 130-141. [CrossRef]

25. Roberts, S.; Xin, H.; Kerr, J. Effects of dietary fiber and reduced crude protein on nitrogen balance and egg production in laying hens. Poult. Sci. 2007, 86, 1716-1725. [CrossRef]

26. Roberts, S.; Bregendahl, K.; Xin, H. Adding fiber to the diet of laying hens reduces ammonia emission. Anim. Indus. Rep. 2006. [CrossRef]

27. National Research Council, NRC. Nutrient Requirements of Poultry; National Academies Press: Washington, DC, USA, 1994. [CrossRef]

28. Radwan, N.; Hassan, R.; Qota, E.; Fayek, H. Effect of natural antioxidant on oxidative stability of eggs and productive and reproductive performance of laying hens. Int. J. Poult. Sci. 2008, 7, 134-150. [CrossRef]

29. Saleh, A.; Ahmed, E.; Ebeid, A. The impact of phytoestrogen source supplementation on reproductive performance, plasma profile, yolk fatty acids and antioxidative status in aged laying hens. Reprod. Domest. Anim. 2019, 54, 846-854. [CrossRef] [PubMed]

30. Surai, P. Vitamin E and egg quality. Qual. Eggs Egg Prod. 1995, 5, 387-394. [CrossRef]

31. Ulbricht, T.L.V.; Southgate, D.A.T. Coronary heart disease: Seven dietary factors. Lancet 1991, 338, 985-992. [CrossRef]

32. Arakawa, K.; Sagai, M. Species differences in lipid peroxide levels in lung tissue and investigation of their determining factors. Lipids 1986, 21, 769-775. [CrossRef]

33. AOAC. Official Method of Analysis, 16th ed.; Association of Official Analytical Chemists: Washington, DC, USA, 1995. [CrossRef]

34. Furlan, A.; Mantovani, A.; Murakami, A. Use of sunflower meal in broiler chicks feeding. Rev. Bras. Zootec. 2001, 30, 158-164. [CrossRef]

35. Sunil, K. Usage of decorticated sunflower meal in feed formulation. Int. J. Chem. Stud. 2019, 6, 212-215. [CrossRef]

36. Laudadio, V.; Tufarelli, V. Treated fava bean (Vicia faba var. minor) as substitute for soybean meal in diet of early phase laying hens: Egg-laying performance and egg quality. Poult. Sci. 2010, 89, 2299-2303. [CrossRef] [PubMed]

37. Laudadio, V.; Tufarelli, V. Influence of substituting dietary soybean meal for dehulled-micronized lupin (Lupinus albus cv. Multitalia) on early phase laying hens production and egg quality. Livest. Sci. 2011, 140, 184-188. [CrossRef]

38. Al-Shami, M.A.; Salih, M.E.; Abbas, T.E. Effects of dietary inclusion of alfalfa (Medicago sativa L.) leaf meal and Xylan enzyme on laying hens' performance and egg quality. Res. Opin. Anim. Vet. Sci. 2011, 2, 14-18. [CrossRef]

39. Senkoylu, N.; Dale, N. Nutritional evaluation of a high-oil sunflower meal in broiler starter diets. J. Appl. Poul. Res. 2006, 15, 40-47. [CrossRef] 
40. Güçlu, B.K.; Işcan, K.M.; Uyanik, F.; Eren, M.; Ağca, A.C. Effect of alfalfa meal in diets of laying quails on performance, egg quality and some serum parameters. Arch. Anim. Nutr. 2004, 58, 255-263. [CrossRef]

41. Costa, F.; Souza, J.; Goulart, R. Desempenho e qualidade dos ovos de poedeiras semipesadas alimentadas com dietas contendo óleos de soja e canola. Rev. Bras. Zootec. 2008, 37, 1412-1418. [CrossRef]

42. Simopoulos, A. Human requirement for N-3 polyunsaturated fatty acids. Poult. Sci. 2000, 79, 961-970. [CrossRef]

43. Ramos, M.J.; Fernández, C.M.; Casas, A.; Rodríguez, L.; Pérez, Á. Influence of fatty acid composition of raw materials on biodiesel properties. Bioresour. Technol. 2009, 100, 261-268. [CrossRef]

44. Ebeid, T.; Eid, Y.; Saleh, A.; Abd El-Hamid, H. Ovarian Follicular Development, Lipid Peroxidation, Antioxidative Status and Immune Response in Laying Hens Fed Fish Oil Supplemented Diets to Produce Omega-3 Enriched Eggs. Animal 2008, 2, 84-91. [CrossRef] [PubMed]

45. Dorrell, D.; Vick, B. Properties and processing of oilseed sunflower. Sunflower Tech. Prod. 1997, 35, 709-745. [CrossRef]

46. Morrison, W. Effects of refining and bleaching on oxidative stability of sunflower seed oil. J. Am. Oil Chem. Soc. 1975, 52, 513-522. [CrossRef]

47. Laudadio, V.; Ceci, E.; Lasstella, N.; Tufarelli, V. Dietary high-polyphenols extra-virgin olive oil is effective in reducing cholesterol content in eggs. Lipids Health Dis. 2015, 14, 5. [CrossRef] [PubMed]

48. Liu, X.; Zhao, H.; Thiessen, S.; House, J. Effect of plant sterol-enriched diets on plasma and egg yolk cholesterol concentrations and cholesterol metabolism in laying hens. Poult. Sci. 2010, 89, 270-275. [CrossRef]

49. Karunajeewa, H.; Abu-Serewa, S.; Tham, H.; Eason, P. The effects of dietary level of sunflower seeds and lysine on egg quality and laying performance of White Leghorn hens. J. Sci. Food Agric. 1987, 41, 325-333. [CrossRef]

50. Senkoylu, N.; Dale, N. Sunflower meal in poultry diets: A review. World's Poult. Sci. J. 1999, 55, 153-174. [CrossRef]

51. Bedford, M.; Classen, H. Reduction of intestinal viscosity through manipulation of dietary rye and pentosanase concentration is affected through changes in the carbohydrate composition of the intestinal aqueous phase and results in improved growth rate and food conversion efficiency of broiler chicks. J. Nutr. 1992, 122, 560-569. [CrossRef]

52. Wu, Y.; Nichols, N. Fine grinding and air classification of field pea. Cereal Chemist. 2005, 82, 341-344. [CrossRef]

53. Saleh, A.A.; Elnagar, A.M.; Eid, Y.Z.; Ebeid, T.A.; Amber, K.A. Effect of feeding wheat middlings and calcium lignosulfonate as pellet binders on pellet quality growth performance and lipid peroxidation in broiler chickens. Vet. Med. Sci. 2020, 7, 194-203. [CrossRef]

54. Saleh, A.A.; Zaki, A.; El-Awady, A.; Amber, K.; Badwi, N.; Eid, Y.; Ebeid, T.A. Effect of substituting wheat bran with cumin seed meal on laying performance, egg quality characteristics and fatty acid profile in laying hens. Vet. Arhiv 2020, 90, 47-56. [CrossRef]

55. Wu, Y.; Abbott, P. Protein enrichment of defatted salicornia meal by air classification. J. Am. Oil Chem. Soc. 2003, 80, 167-169. [CrossRef]

56. Gunawardena, C.; Zijlstra, R.; Beltranena, E. Characterization of the nutritional value of air-classified protein and starch fractions of field pea and zero-tannin faba bean in grower pigs. J. Anim. Sci. 2010, 88, 660-670. [CrossRef]

57. Saleh, A.A.; Kirrella, A.A.; Dawood, M.; Ebeid, T.A. Effect of dietary inclusion of cumin seed oil on the performance, egg quality, immune response and ovarian development in laying hens under high ambient temperature. J. Anim. Physiol. Anim. Nutr. 2019, 103, 1810-1817. [CrossRef] [PubMed]

58. Saleh, A.A.; Hayashi, K.; Ijiri, D.; Ohtsuka, A. The influence of dietary supplementation with Aspergillus awamori and feeding canola seed on the growth performance and meat quality in male broilers chickens. J. Anim. Sci. 2015, 86, 305-311. [CrossRef] [PubMed]

59. Saleh, A.A.; Paray, P.A.; Dawood, M.O. Olive Cake Meal and Bacillus licheniformis Impacted the Growth Performance, Muscle Fatty Acid Content, and Health Status of Broiler Chickens. Animals 2020, 10, 695. [CrossRef] 